\title{
Undergraduate nursing students' opinions and attitudes toward organ donation: a survey in a Turkish university
}

\author{
Fatma Cebeci $^{* 1}$, Gülten Sucu Dağ ${ }^{2}$, Ebru Karazeybek ${ }^{1}$ \\ ${ }^{1}$ Faculty of Nursing, Akdeniz University, Antalya, Turkey \\ ${ }^{2}$ Faculty of Health Sciences, Dogu Akdeniz University, Mersin, Turkey
}

Received: March 29, 2015

Accepted: June 16, 2015

Online Published: June 23, 2015

DOI: $10.5430 /$ jnep.v5n9p83

URL: http://dx.doi.org/10.5430/jnep.v5n9p83

\begin{abstract}
This study was conducted to determine undergraduate nursing students' opinions and attitudes about organ donation. Three hundred and four undergraduate nursing students participated in the survey while studying at Akdeniz University in the 2008 spring semester. Although these data were collected in 2008, there is still very little literature on this topic and the need for transplant organs is as urgent now as it was at that time. The data were obtained from a questionnaire. The questionnaire results reflected that the expert opinion was consistent with Kendall's concordance analysis. Written consent was obtained from each student. The data were analyzed by descriptive statistics, the chi-square test and Spearman's correlation. Among the students, $66.1 \%$ received training about organ donation, and 59.5\% received this training from the Nursing School, 12.2\% were organ donors, $45.3 \%$ of the family members were ambivalent about organ donation, $18.7 \%$ were willing to donate organs to save lives, and $21.2 \%$ refused to donate organs for fear of the removal of organs before one's death in the event of an accident or serious injury. $65.8 \%$ of the students were willing to donate their organs while alive. There were significant differences between donating an organ and receiving training $(p<.05)$. This study also analyzed income state, age and sex and found no significant difference in donating organs for each of these variables $(p>.05)$. Nursing students' positive thoughts about organ transplantation and donation should be promoted and relevant training and seminars, particularly about barriers to organ donation, should be increased.
\end{abstract}

Key Words: Organ donation, Nursing student, Opinions, Attitudes, Survey

\section{INTRODUCTION}

Organ/tissue transplantation is a process in which a nonfunctioning organ or a tissue is replaced with a healthy organ or tissue removed from a living or deceased donor. ${ }^{[1,2]}$ Transplantation gives patients who have end-state failure of a vital organ a second chance of living. ${ }^{[2]}$ Organ transplantation is an important health problem in Turkey and worldwide. The shortage of donors is to blame for patients dying while on the waiting list for a liver, heart or lung transplant. The number of patients waiting for organ transplantation is progressively increasing. ${ }^{[1,3-6]}$ One of the most important stages of organ transplantation is the procurement of organs, but the most significant barriers are insufficient organ and tissue donation, ${ }^{[1,2,7-11]}$ despite considerable developments in organ transplantation..$^{[1,2,9]}$

The National Organ and Tissue Transplantation Coordination Turkey.

*Correspondence: Fatma Cebeci; Email: fcebeci@akdeniz.edu.tr; Address: Faculty of Nursing, Akdeniz University, 07058, Campus/Antalya, 
System was established under the control and coordination of the Ministry of Health in Turkey. ${ }^{[12,13]}$ Despite the presence of transplant centers with adequate facilities, an insufficient number of organ donations appears to be the most important factor that prevents organ transplantation. ${ }^{[2,7,10]}$ The current rate of organ donations in Turkey needs to be increased at least 15 -fold to reach the level of organ donation that exists in other countries. ${ }^{[4-7,11]}$ Every member of society, particularly health professionals, should have sufficient knowledge and awareness of organ donation. ${ }^{[7,8]}$ Health care professionals are key to increasing organ donation because of their communication with patients and their relatives. ${ }^{[12]}$ Research suggests that nursing students have insufficient knowledge about organ donation. ${ }^{[2,14-17]}$ However, training about donation is reported to increase the level of knowledge about donation and the willingness to donate. ${ }^{[10,18]}$ The literature shows that $34.9 \%$ to $72.3 \%$ of students in Turkey are willing to donate, ${ }^{[16,17,19]}$ and the rate of organ donation in Turkey ranges from $1.7 \%$ to $5.3 \% .{ }^{[2,20-22]}$ However, the rate of organ donation as reported by international studies ranges from $11 \%$ to $74 \% .^{[18,23]}$ In a study conducted on third-year nursing $(\mathrm{n}=50)$ and medical students $(\mathrm{n}=50)$, Cantwell and Clifford $^{[23]}$ found that $74 \%$ of nursing students were more willing to donate organs and attached more importance to donation than medical students (43\%). The nursing students' motives for organ donation were reported as giving a new life to people, ${ }^{[24]}$ helping patients, ${ }^{[7,16]}$ serving humanity ${ }^{[8]}$ and religious beliefs. ${ }^{[16]}$ On the other hand, the causes for refusing to donate organs included preservation of an intact body after death, religious beliefs ${ }^{[17]}$ and concern that donated organs might be abused. ${ }^{[10]}$

Cebeci et al. ${ }^{[25]}$ found that nurses' roles could be classified as "increasing public awareness"; "caring for recipients, donors, and their families"; "conducting research"; "supporting related organizations"; and "being a role model for the public".

Studies on nursing students' organ donation and transplantation examine the factors affecting their knowledge, perceptions and beliefs about organ donation; the effect of education and knowledge of organ donation; and the roles of nursing students and nurses in organ donation. One's attitudes toward donation can be decisive in his or her registration for organ donation. ${ }^{[8]}$ The development of strategies to determine nursing students' opinions and attitudes toward organ donation is significant to revising the relevant curricula, eliminating the deficiencies in the educational process and correcting false beliefs about organ donation. ${ }^{[3,14,15]}$ Our research revealed that only a few studies have focused on determining student attitudes and opinions about organ donation. This study focused on determining the opinions and attitudes of nursing students, who are regarded as future health professionals. This issue is significant for the correcting of misinformation and beliefs about organ donation and the planning of activities to guide the content of relevant curricula. The study also aimed to identify areas for improvement in the curricula of nursing training institutions, so that they can offer sufficient teaching and clinical experience with respect to organ donation.

As future health care professionals, nursing students' opinions and attitudes about donation can affect their approach to brain-dead patients and the decision-making process of these patients' family members in organ donation. For this reason, it is important to identify the factors that adversely affect nursing students' opinions, attitudes and participation regarding donation. In this light, the study was conducted as a descriptive one to determine nursing students' opinions and attitudes about organ donation.

\section{MethodS}

\subsection{Design}

We performed a cross-sectional study because this design studies characteristics of a phenomenon in a population and the relationship between different variables at a given point in time. The data were obtained via a questionnaire prepared by the researchers in light of the literature ${ }^{[7,8,10,15,19]}$ and based on expert opinions that were obtained from eight nursing faculty members. Kendall's coefficient of concordance analysis proved the expert opinions to be consistent with each other (Kendall's W: 0.126, $p=.006$ ). The questionnaire was pilot-tested on a random sample of nursing students regarding wording and the time needed for completion. After pilot testing, two items that were misunderstood by most candidates were dropped from the questionnaire. All participants who filled out the questionnaire for pilot testing were excluded from the study. The questionnaire consisted of 24 items: 7 items pertaining to socio-demographic characteristics of the participants and 17 items involving the opinions and attitudes of the students concerning organ donation and the willingness to donate organs. Respondents were given three options regarding opinions and attitudes: yes, no and other-specify.

\subsection{Sample}

The study included three hundred and four nursing students who were studying at Akdeniz University Antalya and the Akseki Schools of Health. We selected these schools because there were nursing schools in Antalya. 310 of the total 412 students agreed to participate in the study and filled out the questionnaires. 6 students' questionnaires were excluded from the study because they previously participated in the 
pilot study. The final response rate was $73.7 \%$ (304 out of 412).

\subsection{Data collection methods}

One of the researchers (GSD) visited each nursing school during the final week of 2008. The background and intentions of the survey were explained and the students were encouraged to participate without any undue pressure. Students completed a self-administered quantitative questionnaire. Immediately following its completion, the same researcher collected the questionnaires.

\subsection{Ethics}

The review board and coordinators of each of the participating nursing schools approved all study procedures. Before the questionnaires were distributed, the background and intentions of the survey were explained and the students were encouraged to participate without any undue pressure. Written consent was obtained from each student.

\subsection{Data analysis}

The data obtained in the present study were entered in The Statistical Package for the Social Sciences (SPSS, version 11.0, Chicago, IL USA), coding all categories of the variables. Descriptive statistics were used to describe respondents' characteristics. The Kendall Coefficient of Concordance was used to assess the feasibility and intelligibility of the survey items. Categorical variables were presented as counts and percentages for each category. A comparison of the situation between students receiving training and organ donation was conducted using $\chi^{2}$ (McNemar Test). Relationships between the presence of organ donation and received training places were evaluated by calculating Spearman's correlation coefficient. The $\chi^{2}$ test and Fisher's exact test were used to compare income status, age, sex and organ donation. All tests were two-tailed and conducted at a statistical significance level of .05 .

\section{Results}

Among the three hundred and four students in the study, 80.6\% attended the Antalya School of Health, and 19.4\% attended the Akseki School of Health. Their mean age was $21.1 \pm 1.4$. $28.6 \%$ were fourth-year students, $97.1 \%$ were female, $3.9 \%$ were male, $97.0 \%$ were high-school graduates, $3.0 \%$ were vocational high-school graduates, $63.8 \%$ had a balanced income-expenditure ratio, $52.6 \%$ spent most of their lives in the city center, and $44.7 \%$ considered themselves religious individuals. According to the descriptive characteristics and opinions of the nursing students in the study (see Table 1), 66.1\% of them received training about organ donation, and $59.5 \%$ received this training at nursing Published by Sciedu Press school. Among the participants, $12.2 \%$ were already registered as organ donors and $38.8 \%$ were willing to donate organs. The percentage of students who stated that their families were aware of their opinions about organ donation was $53.9 \%$. Some of the students were willing to donate and others were ambivalent about donating organs. 39.1\% of those students who were willing to donate organs also stated that they would donate the organs/tissues of their relatives who did not make an advanced statement against doing so. Additionally, $65.8 \%$ of students were willing to donate their organs while alive. Most students' family members had positive opinions or were ambivalent about organ donation.

A significant difference was found between organ donation and received training $\left(p<.05, \chi^{2}=1.221\right)$ (see Table 2). However, there was no correlation between the presence of organ donation and received training places $(r=1.445, p>$ $.05)$. This study also analyzed income status, age and sex and found no significant difference in organ donation for each of these variables $(p>.05)$.

As seen in Table 3, some of the reasons participants gave for donating/willingness to donate organs were "saving lives", "helping people", "thinking that his or her beloved ones may need organ donation one day", and "helping people realize their hopes".

Table 4 shows the reasons participants gave for not donating/not being willing to donate organs. The three most important reasons were "fear of removal of organs before one's death in the event of an accident or serious", "not feeling ready to think about death", and "distrust of doctors".

\section{Discussion}

This study examined the opinions and attitudes of nursing students toward organ donation. Three hundred and four students participated in the study, and more than half of the students were found to have prior information about organ donation. There were significant differences between organ donation and receiving training $(p<.05)$ (see Table 2$)$. However, there was no correlation between the presence of organ donation and training places $(r=1.445, p>.05)$. This finding may be due to training being received from multiple sources. While the students obtained most of their information about organ donation from the school, visual and printed media were also used as primary sources of information. Studies reported both high ${ }^{[10,17,20]}$ and low ${ }^{[2,7,15]}$ levels of knowledge about organ donation. Most of the research on the means of obtaining information about organ donation found that visual and printed media (television, newspapers, magazines, etc.) made an important contribution to the respondents' knowledge about organ donation. ${ }^{[8,15,17]}$ The study found that 
individuals are affected by negative news (see Table 4) in the media twice as much as positive news (see Table 3 ). For this reason, it is important that positive news be presented in the media. This study's findings suggest that educational courses and seminars about organ donation are the most effective sources of information to increase students' level of knowl- edge on the subject. Therefore, it is essential that courses and seminars address negative and unrealistic reasons that prevent donation, such as the removal of one's organs before his or her death and the belief that organ donation is against one's religious beliefs.

Table 1. Descriptive information about the nursing students and their opinions concerning organ donation $(\mathrm{n}=304)$

\begin{tabular}{|c|c|c|}
\hline Descriptive Information about students & $\mathbf{N}$ & $\%$ \\
\hline \multicolumn{3}{|l|}{ Receiving training about organ donation } \\
\hline Receiving training & 201 & 66.1 \\
\hline Not receiving training & 103 & 33.9 \\
\hline \multicolumn{3}{|c|}{ The place(s) where information and/or training about organ donation was received* } \\
\hline School-Lessons & 181 & 59.5 \\
\hline Newspaper-Magazine-Brochure & 94 & 27.6 \\
\hline Radio-TV & 72 & 23.7 \\
\hline Seminars-Conferences & 65 & 21.4 \\
\hline Friends & 27 & 7.9 \\
\hline Family & 10 & 2.9 \\
\hline Other & 7 & 2.3 \\
\hline \multicolumn{3}{|l|}{ Donating organs } \\
\hline No donate & 267 & 87.8 \\
\hline Donate & 37 & 12.2 \\
\hline \multicolumn{3}{|l|}{ Willing to donate organs } \\
\hline Not willing & 26 & 8.6 \\
\hline Willing & 118 & 38.8 \\
\hline Ambivalent & 160 & 52.6 \\
\hline \multicolumn{3}{|c|}{ Family being aware of one's opinions about organ donation } \\
\hline Not being aware & 140 & 46.1 \\
\hline Being aware & 164 & 53.9 \\
\hline \multicolumn{3}{|c|}{ Opinions of family members about organ donation } \\
\hline Positive & 114 & 37.5 \\
\hline Negative & 52 & 17.1 \\
\hline Ambivalent & 138 & 45.3 \\
\hline \multicolumn{3}{|c|}{ Willingness to be living donors for family members and friends when necessary } \\
\hline Not willing & 20 & 6.6 \\
\hline Willing & 200 & 65.8 \\
\hline Ambivalent & 84 & 27.6 \\
\hline \multicolumn{3}{|c|}{ Donating the organs/tissues of relatives who did not make an advance statement against it after their death } \\
\hline Not donate & 54 & 17.8 \\
\hline Donate & 119 & 39.1 \\
\hline Ambivalent & 131 & 43.1 \\
\hline
\end{tabular}

* The figures are presented as a percentage of the total number of responses.

Table 2. Comparison of the situation between students receiving training and organ donation $(\mathrm{n}=304)$

\begin{tabular}{|c|c|c|c|c|}
\hline & \multicolumn{2}{|c|}{ Donating organs } & \multirow{2}{*}{ Total } & \multirow{2}{*}{$\begin{array}{l}\chi^{2} \\
\text { (McNemar Test) }\end{array}$} \\
\hline & No & Yes & & \\
\hline \multicolumn{5}{|c|}{ Receiving Training } \\
\hline No & 103 & 9 & 112 & $\chi^{2}=1.221$ \\
\hline Yes & 164 & 28 & 192 & $P=.00$ \\
\hline Total & 267 & 37 & 304 & \\
\hline
\end{tabular}


Table 3. Reasons of the nursing students for donating/willing to donate organs $(\mathrm{n}=1268)$

\begin{tabular}{lll}
\hline Reasons for Donating/Willing to Donate Organs * & N & \% \\
\hline Saving lives & 237 & 226 \\
Helping people & 220 & 17.8 \\
Thinking that that one or his or her beloved ones may need organ donation one day & 214 & 17.4 \\
Helping people realize their hopes & 168 & 16.9 \\
Thinking that one's organs serve for something and continue to exist & 101 & 13.2 \\
Continuing to live in someone else's body & 45 & 8.0 \\
Not forcing one's parents to make a decision on one's behalf after his or her death & 21 & 3.6 \\
Being influenced by positive news in printed and visual media such as TV/Newspaper & 20 & 1.7 \\
Earning others' respect & 16 & 1.6 \\
Other (Being influenced by friends/relatives, seeking excitement) & 1.3 \\
\hline
\end{tabular}

*The number $\mathrm{n}$ increased because there were multiple responses and the percentages were taken based on the total number of responses.

Table 4. Reasons of the nursing students for not donating/not willing to donate organs $(n=699)$

\begin{tabular}{lll}
\hline Reasons for Not Donating/Not Willing to Donate Organs* & $\mathbf{N}$ & \% \\
\hline Fear of removal of organs before one's death in the event of an accident or serious injury & 148 & 21.2 \\
Not feeling ready for thinking about death & 134 & 19.2 \\
Distrust in doctors & 101 & 14.4 \\
Wish to preserve an intact body after death & 89 & 60 \\
Feeling discouraged & 57 & 8.6 \\
Lack of knowledge on organ donation and organ donation process & 48 & 8.1 \\
Family refusal & 33 & 6.9 \\
Against religious beliefs & 22 & 3.7 \\
Being influenced by negative news in printed and visual media such as TV/Newspaper & 7 & 3.1 \\
Feeling uncomfortable with one's organs living in another body & 1.1 \\
\hline
\end{tabular}

* The number $n$ increased because there were multiple responses and the percentages were taken based on the total number of responses.

The study found that $12.2 \%$ of the students in the study were already registered as donors. The literature shows that the rate of donation among students in Turkey ranges from $1.7 \%$ to $5.3 \% .^{[2,20-22]}$ The percentage of students registered as donors was higher than the average in Turkey. The main source of students' information on the subject was school. School education can be considered to be effective in this regard. These results show that the rate of organ donation in Turkey still needs to be increased. In fact, the rate of organ donation as reported by international studies ranges from $11 \%$ to $74 \% .^{[3,23]}$

The study found that the percentage of students who were willing to donate was three times more than those who donated organs (see Table 1). This finding is similar to those from other studies, which found that the percentage of students willing to donate was high, ${ }^{[16,19]}$ but the percentage of students donating was low. ${ }^{[20-22]}$ This situation indicates a need to elaborately study the barriers to organ donation. The most important factor that prevents organ transplantation in Turkey is the insufficient number of organ donations. Achieving the desired level of organ donation requires involving nursing students, who are future health care professionals, in the process, increasing the number of training and seminars about organ donation based on needs, and planning projects that will assign students an active role in organ donation. Additionally, there should be more effective participation in educational activities, institutions and organizations about organ donation in Turkey, which might help to resolve this problem. ${ }^{[7]}$ Additionally, nursing students who were willing to donate organs $(38.8 \%)$ stated that they would donate the organs/tissues of their relatives who did not make an advanced statement against doing so (39.1\%). This study's finding is interesting in terms of increasing organ donation. In this sense, another interesting finding is that only $46.1 \%$ of students informed their families about their opinions on organ donation. Currently in Turkey, even if a person with brain death donated their organs before their death, their organs cannot be removed without their family members' consent. For this reason, it is important that the students who donated organs or were willing to donate organs inform their families about this situation. López-Montesinos et al. ${ }^{[18]}$ found that, as a result of the training given to improve thirdyear nursing students' knowledge of organ donation, $83 \%$ of the students' families were aware of their thoughts on organ donation, the training program promoted organ donation, and 
conversations within the family on organ donation increased awareness of this issue.

In this study, $38.8 \%$ of students were willing to donate organs, and the percentage of students who stated that when necessary, they would serve as living donors for family and friends was $65.8 \%$. In Turkey, family ties are typically strong, and this may be a factor that increases the desire to be living organ donors in this country. On the other hand, the students' distrust of physicians handling of the organs donated appears to be a factor that decreases organ donation, but increases the rate of living donors.

Reasons participants gave for their willingness to donate organs included "saving lives" and "helping people" (see Table 3). This study's results are consistent with results from similar studies. The reported reasons for donating organs were giving new life to people at $40 \%$ to $44 \%,{ }^{[24]}$ helping patients at $46.1 \%$ to $88.5 \%{ }^{[7,16]}$ and serving humanity at $82.2 \% .^{[8]}$ Research suggests that the causes of unwillingness to donate organs include lack of knowledge, belief that hospital staff will not work as hard to save one's life, religious beliefs, medical insecurities, fear of organ trafficking, and concerns about the preservation of an intact body and the abuse of donated organs. ${ }^{[2,7,16,17,19,26,27]}$ The same reasons participants gave for their unwillingness to donate included "fear of removal of organs before one's death in the event of an accident or serious injury" and "distrust of doctors" (see Table 4). These results show that prospective health professionals do not trust their prospective colleagues. Addressing and eliminating the adverse situations affecting students' decisions on the issue could also have a positive impact on their family members.

It is clear that the students should be more efficiently informed about the fact that in the transplantation process, decisions about brain death and organ transplantation are made by two experts (a neurologist or a neurosurgeon and an anesthesiology and reanimation specialist or intensive care specialist) and that the process of organ and tissue transplantation in Turkey is regulated by "the Law of Organ and Tissue Procurement, Preservation, Grafting and Transplantation". ${ }^{[13]}$

Covering these issues in the relevant curricula and adopting specific educational strategies could help to ensure that health professionals, who are supposed to lead society in this regard, obtain sufficient knowledge about donation and transplantation during their training. ${ }^{[10,28,29]}$ In addition, informing society about the donation process, creating an environment in which students are able to observe the processes of transplantation during clinical applications and providing students with more opportunities to take part in the process of clinical practice could help decrease these con88 cerns. ${ }^{[28]}$ Media reports about people who illegally obtain organs could be considered to play a role in misdirection of the public. It is crucial that organ transplantation training, research and application centers have close and positive communication with the media, so that misinformation about the issue can be prevented, and the media can be appropriately guided about transplantation and donation. ${ }^{[8]}$ Nursing students' opinions and attitudes about donation can affect their willingness and that of their family and friends to donate organs, their approach to brain-dead patients and their family members' decision-making process.

\section{Conclusion}

This study examined the opinions and attitudes of nursing students, who are regarded as prospective health professionals who can play a key role in increasing social awareness, about organ donation. The study found that students obtained most of their information about organ donation via school education. The percentage of students registered as donors was higher than the donation rate in Turkey, but it was lower than the rates in developed countries. About half of the students' families were aware of their thoughts about organ donation.

In light of these results, it is recommended that nursing students' positive thoughts about organ transplantation and donation be promoted, the number of relevant trainings and seminars about this issue be increased so that their thoughts can turn into actions, cooperation with organ transplantation units be developed and nursing students undertake an active role in public training activities about organ donation. To develop positive behavior in individuals, it is vital that the number of educational activities about the barriers to donation and positive television programs be increased and that necessary action be taken by organ donation institutions and organizations so that false news in the media can be prevented.

Organ transplantation is an important health problem in Turkey and worldwide. The number of patients waiting for organ transplantation is progressively increasing, and the most significant barriers to organ transplantation are insufficient organ and tissue donation. As future health care professionals, nursing students may play a key role in increasing organ and tissue donation and social awareness.

\section{ACKNOWLEDGEMENTS}

The authors are especially grateful to all the students who participated in this study. This study received the external funding from Akdeniz University Scientific Research Projects Management Unit.

\section{CONFLICTS OF INTEREST DisClOSURE}

The authors declare that there is no conflict of interest. 


\section{REFERENCES}

[1] Aktaş YY, Karabulut N. Giresun Üniversitesi Sağlık Bilimleri Fakültesindeki Hemşirelik Öğrencilerinin Beyin Ölümü ve Organ Bağışına İlişkin Bilgi ve Tutumları (Knowledge and Attitudes of Nursing Students Who Have Been Training in Giresun University Faculty of Health Sciences about Brain Death and Organ Donation). Firat Tip Dergisi. 2012; 17(3): 129-134.

[2] Özer A, Ekerbiçer HC, Çelik M, et al. Knowledge, Attitudes, and Behaviors of Officials of Religion About Organ Donation in Kahramanmaras, an Eastern Mediterranean City of Turkey. Transplant Proceedings. 2010; 42(9): 3363-7. PMid:21094780 http://dx.d oi.org/10.1016/j.transproceed.2010.08.035

[3] Zampieron A, Corso M, Frigo AC. Undergraduate nursing students' attitudes towards organ donation: a survey in an Italian university. International Nursing Review. 2010; 57(3): 370-376. PMid:20796068 http://dx.doi.org/10.1111/j.1466-7657.2010.00806.x

[4] U.S. Department of Health \& Human Services. OPTN Organ Procurement and Transplantation Network. 2014.

[5] Eurotransplant Cooperating saves lives. 2014.

[6] Köse MR, Başara B, Güler C, et al. (Ed) 2013 Number of Organ Transplantations by Years, Turkey in The Ministry of Health of Turkey Health Statistics Yearbook. Sentez Mat. Ankara. Turkey; 2013. Available from: http://ekutuphane.sagem.gov.tr/ki taplar/health_statistics_yearbook_2013.pdf

[7] Göz F, Göz M, Erkan M. Knowledge and attitudes of medical, nursing, dentistry and health technician students towards organ donation: a pilot study. Journal of Clinical Nursing. 2006; 15(11): 13715. PMid:17038097 http://dx.doi .org/10.1111/j.1365-270 $2.2006 .01431 . x$

[8] Özmen D, Çetinkaya AC, Sarızeybek B, et al. Celal Bayar Üniversitesi Manisa Sağlık Yüksekokulu Öğrencilerinin Organ Bă̆ışına İlişkin Bilgi ve Görüşleri. Türkiye Klinikleri J Med Sci. 2008; 28 (3): 311-18.

[9] Anker AE, Feeley TH, Friedman E, et al. Teaching organ and tissue donation in Medical and nursing education: a needs assessment. Progress in Transplantation. 2009; 19(4): 343-8. http: //dx.doi.org/10.7182/prtr.19.4.4n1p6q464j6v0666

[10] Gök ÖF, Karamanoğlu AY, Beydağ KD, et al. Yüksekokulunda öğrenim gören bir grup öğrencinin organ nakli/bağışına yönelik görüşleri ve bilgi düzeylerine eğitimin etkisi. TAF Prev Med Bull. 2008; 7(1): 39-46.

[11] Zheng P, Sammann A, Qiu M, et al. Impact of preclinical exposure to organ donation on knowledge and attitudes of medical students. Progress in Transplantation. 2012; 22(1): 79-85, 109. PMid:22489447 http://dx.doi.org/10.7182/pit2012267

[12] The Ministry of Health of Turkey. "Organ ve doku alınması, saklanması ve nakli hakkında" 29.05.1979 tarihli 2238 sayılı kanun. 1982 tarih ve 2594 sayılı kanunun 1. maddesiyle değiştirilmiş metni. 2010.

[13] The Ministry of Health of Turkey. 6514 sayılı Sağlık Bakanlığı ve Bağlı Kuruluşlarının Teşkilat ve Görevleri Hakkında Kanun Hükmünde Kararname İle Bazı Kanunlarda Değişiklik Yapılmasına Dair Kanun, 18.01.2014 tarih ve 28886 sayılı Resmi Gazete Madde 41. 2014.

[14] Özerb N, Saritaş K, Özlü Z, et al. Hemşirelik Öğrencilerinin Organ Nakli ve Bağışı Konusundaki Bilgi ve Düşüncelerinin İncelenmesi. Anadolu Hemşirelik ve Sağlık Bilimleri Dergisi. 2010; 13(2): 1-11.
[15] Kim JR, Fisher MJ, Elliott D. Undergraduate nursing students' knowledge and attitudes towards organ donation in Korea: Implications for education. Nurse Education Today. 2006; 26(6): 46574. PMid:16540211 http://dx.doi.org/10.1016/j.nedt. 20 06.01 .003

[16] Savaşer S, Mutlu B, Çağlar S, et al. Hemşirelik Son Sınıf Öğrencilerinin Organ Bağışına Bakışları. İ.Ü.F.N. Hemşirelik Dergisi. 2012; 20(1): 1-9.

[17] Üstüner F, Uysal A, Kaya B. Giresun Üniversitesi Sağlık Yüksekokulu Öğrencilerinin Organ Bağışı ve Nakli Hakkındaki Bilgi, Tutum ve Düşünceleri. Dikimevi Sağlık Hizmetleri Meslek Yüksekokulu Dergisi DSHMYD. 2009; 8(1): 1-9.

[18] López-Montesinos MJ, Manzanera Saura JT, Mikla M, et al. Organ donation and transplantation training for future Professional nurses as a health and social awareness policy. Transplantation Proceedings. 2010; 42(1): 239-42. PMid:20172319 http://dx.doi.org/10. 1016/j.transproceed.2009.11.008

[19] Yaşar M, Oğur R, Uçar M, et al. Bir sağlık yüksekokulu son sınıf öğrencilerinin organ bağışı konusundaki tutumları ve tutumlarına etki eden faktörler. Genel Tıp Dergisi. 2008; 18(1): 33-7.

[20] Vicdan AK, Peker S, Üçer B. Akşehir sağlık yüksekokulu öğrencilerinin organ bağişi ile ilgili tutumlarinin belirlenmesi. TAF Prev Med Bull. 2011; 10(2): 175-80. http://dx.doi.org/10.5455/p $\mathrm{mb} .20101216024338$

[21] Koçak A, Aktaş EÖ, Şenol E, et al. Ege Üniversitesi Tıp Fakültesi öğrencilerinin organ nakli ve bağışı hakkındaki bilgi düzeyi. Ege Tıp Dergisi. 2010; 49(3): 153-60.

[22] Kılıç S, Koçak N, Türker T, et al. Kız üniversite öğrencilerinin organ bağışı konusundaki tutumları ve bu tutumlarına etki eden faktörler Gülhane Tip Dergisi. 2010; 52(1): 36-40.

[23] Cantwell M, Clifford C. English nursing and medical students' attitudes towards organ donation. Journal of Advanced Nursing. 2000; 32(4): 961-8. PMid:11095236

[24] Pierini L, Valdez P, Pennone P, et al. Teenager Donation: Investigation of 848 High School Students. Transplant Proceedings. 2009; 41(8): 3457-9. PMid:19857770 http://dx.doi.org/10.1016/j .transproceed.2009.09.003

[25] Cebeci F, Sucu G, Karazeybek E. The roles of nurses to augment organ donation and transplantation: a survey of nursing students. Transplant Proceedings. 2011; 43(2): 412-4. PMid:21440720 http: //dx.doi.org/10.1016/j.transproceed.2011.01.048

[26] Irving MJ, Tong A, Jan S, et al. Factors that influence the decision to be an organ donor: a systematic review of the qualitative literature. Nephrol Dial Transplant. 2012; 27(6): 2526-33. PMid:22193049 http://dx.doi.org/10.1093/ndt/gfr683

[27] Kazlulsky W. U.S. Organ Donations: Nurses Can Make a Difference. American Journal of Nursing. 2013; 113(9): 2021. PMid:23985598 http://dx.doi.org/10.1097/01. NAJ.00 00434167.46127 .66

[28] Tam WW, Suen LK, Chan HY. Knowledge, attitudes and commitment toward organ donation among nursing students in Hong Kong. Transplant Proceedings. 2012; 44(5): 1196-200. PMid:22663983 http: //dx.doi.org/10.1016/j.transproceed.2012.01.108

[29] Whisenant DP, Woodring B. Improving attitudes and knowledge toward organ donation among nursing students. International Journal of Nursing Education Scholarship. 2012; 9(1): 1548-51. PMid:22987836 http://dx. doi .org/10.1515/1548-923X. 24 04 